\title{
Cheaper AIDS drugs due for Third World...
}

\section{Phyllida Brown}

The fight against AIDS in the developing world received a boost last week as five pharmaceutical companies joined forces with the United Nations to promote easier access to treatments. Public-health officials welcomed the move, but warned that cheaper drugs alone will not be enough to overcome the HIV epidemic in Africa.

In the same week, US president Bill Clinton issued an Executive Order conceding that African nations can use generic AIDS drugs rather than patented products from US-based companies.

The Joint UN Programme on HIV and AIDS (UNAIDS) and the five drugs companies - Boehringer Ingelheim, Bristol-Myers Squibb, Glaxo Wellcome, Merck and Hoffmann-La Roche - said on 11 May that they had begun a 'dialogue' on improving care and treatment for HIV and AIDS in developing countries.

Cheaper drugs will be one key component of the programme. For example, Glaxo Wellcome says it will now provide its antiHIV combination Combivir (zidovudine and lamivudine), under specific treatment conditions, to developing countries at about $\$ 2$ per day, instead of the usual $\$ 17$ per day.

The UN agencies and other international bodies have been trying for at least a decade to get the price of AIDS drugs cut in Africa. To date, more than 80 per cent of all AIDS-related deaths have occurred in this continent. Recent calls to the industry from UN secretary-general Kofi Annan and UN agency heads for partnerships against AIDS appear to have been behind the companies' decision.

Peter Piot, head of UNAIDS, describes the move as "a promising step in a long-term process". But he warns of the need for "significant new funding" - for example, to ensure that African governments can provide more clinics and trained staff to administer treatment and to monitor patients for the emergence of drug-resistant strains of HIV.

The day before the announcement and, industry spokespersons insist, entirely coincidentally — President Clinton issued his Executive Order. This prevents the US government from punishing any African government that makes or imports cheap generic AIDS drugs or medical technologies, such as HIV diagnostics, instead of patented products from US-based companies. The order lacks full legal status, but can only be overturned by another Executive Order.

Under the Agreement on Trade-Related Aspects of Intellectual Property Rights, governments can use compulsory licensing to allow the production or sale of products without the permission of the patent holder in exceptional conditions, such as publichealth crises.

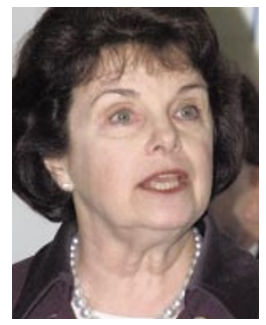

Feinstein: welcomes decision on generics.
In the past, when developing countries have tried to use this provision to make or sell cheaper generic AIDS drugs or diagnostics, the US Trade Representative has opposed them, using retaliatory trade tactics or other leverage.

The new Executive Order says that the US government must "refrain from seeking, through negotiation or otherwise, the revocation or revision" of legislation imposed by African governments to get cheaper AIDS drugs to their populations. But African governments must continue to protect US companies' intellectualproperty rights.
Senator Dianne Feinstein (Democrat, \& California), who has been pushing for such a move, welcomed Clinton's decision. In a statement, she said that the order "will give sub-Saharan governments the flexibility to bring life-saving drugs and medical technologies to affected populations while ensuring that fundamental intellectualproperty rights are protected".

But the American pharmaceutical manufacturers' organization, PhRMA, claims compulsory licensing weakens intellectual-property protection and so reduces the incentive for research into new drugs.

Alan Holmer, PhRMA's president, said last week that Clinton's move "sets an undesirable and inappropriate precedent". PhRMA says it recognizes that AIDS is a major problem, but argues that "weakening intellectual-property rights is not the solution".

\section{...but South Africa voices reservations}

\section{Michael Cherry, Cape Town} South African government officials have reacted cautiously to a deal announced last week by five major companies to slash the price of HIV and AIDS drugs for developing nations (see above). They are concerned that this could undermine efforts to reduce the cost of other medicines.

Patricia Lambert, adviser to South African health minister Manto Tshabalala-Msimang, has said that any effort to bring down drug prices should be welcomed. But she added that concessions for obtaining cheaper AIDS drugs should be applied to other medicines as well.

Lambert was also reported by Dow Jones newswires as saying that "if this offer is attached to a condition that governments like South Africa should not pursue generic substitution, parallel importing and compulsory licensing, then it is not genuine and unacceptable".

But spokespersons for the pharmaceutical industry have denied any formal link between intellectual-property issues and the companies' deal. The deal, announced in Geneva last week, involves Boehringer Ingelheim, Bristol-Myers Squibb, Merck,

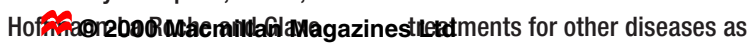
Wellcome.
Both Mirryena Deeb, chief executive of the Pharmaceutical Manufacturers' Association of South Africa, and Peter Moore, medical director in Glaxo Wellcome's Johannesburg office, said they are unaware of any formal link between the offer to reduce the costs of the drugs and patent protection.

Moore suggests that the deal should make the generic substitution of AIDS drugs unnecessary, and says there is no substance to Lambert's suspicions of a hidden agenda to protect the price of other drugs.

"To the contrary, if this programme works with AIDS drugs, there are no reasons why it should not be extended to well," he says. "But the position

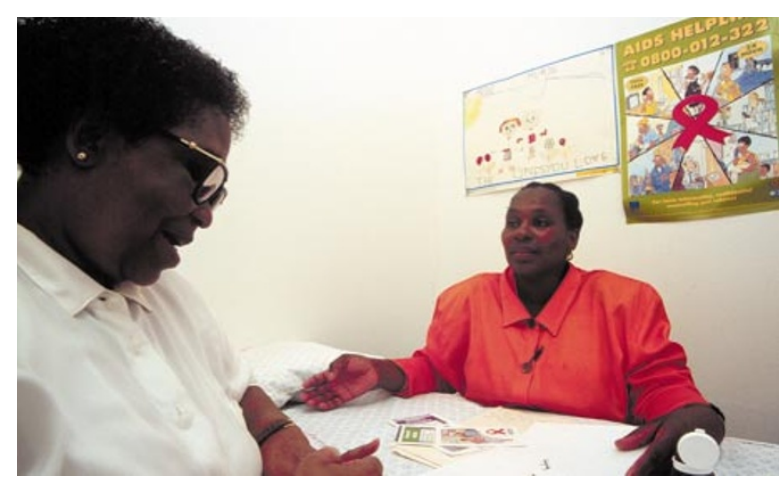

Further AIDS? Concessions 'should be applied to other drugs too'.

will change in South Africa only when the concerned parties are prepared to sit around the table and trust each other."

Last week's announcement came against a backdrop of parliamentary hearings on HIV and AIDS in which health directorgeneral Ayanda Ntsaluba revealed that he had been talking to the trade and industry department with a view to introducing compulsory licensing which would allow access to cheaper drugs.

Deeb called Lambert's statement "disappointing, as she is questioning the bona fides not only of the industry, but of the World Bank and UNAIDS", the agencies that brokered the deal. "If it is true, her statement is an ungracious response to a genuine attempt to make a difference." 